\title{
Ways of EFL Teachers in Developing Their Pedagogical Competences
}

\section{Vivi Aulia}

STKIP PGRI Banjarmasin, Indonesia

Correspondence: Vivi Aulia, STKIP PGRI Banjarmasin; Indonesia. e-mail: viviauliavasa@gmail.com

Submitted: January 02, $2021 \quad$ Revised: February 26, $2021 \quad$ Accepted: March 01, 2021

DOI: $10.29408 /$ veles.v5i1.3032 URL: http://dx.doi.org/10.29408/veles.v5i1.3032

\begin{abstract}
Producing EFL teachers who have the capacity in managing classroom always deal with the mastery of pedagogical competence whether in theory and practice. This study aimed at discussing EFL teachers' views in implementing pedagogy as the way of teaching. This study was called a review article dealing with pedagogical competence. There were ten research articles as the source of data and it was documentation. The analysis data used content analysis because it attempted to apply cross-analysis to find out the main points among the research articles. The study result shows that in order to make EFL teachers manage the classroom activities, they are required to have a bunch of pedagogy knowledge such as designing material, teaching activities, evaluation, and feedback. Besides that, the mastery and literacy of technology are needed to drive EFL teachers to operate teaching-learning media in the effort to enhance learners towards technology-based learning. Using cultural ways in teaching is the way to close the students with the environment to make them easy in getting the knowledge in theory and practice.
\end{abstract}

Keywords: EFL teachers, developing, pedagogical competences

\section{Introduction}

Becoming a professional teacher is a complex matter. The position of the professional teacher plays an important role in creating the success of all education components. The current education policy in Indonesia takes particular requirements in which every teacher should have the required abilities and competencies. Thus, teacher professional development has been carried out to support the effort of increasing teachers' competencies through various programs. Teacher certification programs and other forms of training activities conducted by local as well as national governments or higher education institutions have been implemented for many years as some of the effort to encourage Indonesian teachers to develop their competencies and professionalism.

In the context of education in Indonesia, the overview of the teaching profession, the tasks and the responsibilities of the teacher, and everything related to the role and function of teachers are regulated by national regulation. Act about Teachers and Lecturers No. 14/2005 (Pemerintah 
Republik Indonesia, 2005) becomes the law base of how the Indonesian government regulates the profession of teachers at all levels. This official regulation takes teachers as professional educators with the primary task of educating, teaching, guiding, directing, training, assessing, and evaluating students in all levels of education. Besides that, this law also requires the teacher to have academic qualifications, competencies, official certificate of being professional teachers, healthy condition on their mental and physical matter, and have the ability to support the national education goals (Tanang and $\mathrm{Abu}, 2014$, p.27). Indeed, the teaching profession is different from other professions because there are certain characteristics that should be able to direct learners to the four pillars of education issued by UNESCO (learning to know, learning to do, learning to be, and learning to live together) (Wardoyo, 2015, p.21). To be able to instill those to learners, teachers should have pedagogical competence how to deliver.

As the practice implementation of this law, a teacher as a profession should work hard to perform the competence maximally from the first day of becoming a teacher. The teacher should develop the professional knowledge and understanding of an individual teacher for the smallest thing they can do. In the context of national education policy, the Indonesian government has formulated the four kinds of teacher competencies as mentioned in the explanation of government regulations Number 19 in the Year of 2005 about the national standard of education. They are pedagogical, personal, social, and professional competencies. Each of them has specific indicators representing the ability that teachers should fulfill as a teacher. These competencies support each other so that the teacher will have capability to develop themselves being professional teacher as required by the national regulation.

Pedagogical, personal, social, and professional competencies have their own criteria. Each criterion presents the compulsory task of teachers developing their professionalism as mentioned by official regulation. Pedagogical competence as one of them refers to the ability to manage the process of teaching and learning activities. It includes the understanding of learners, designing and implementing the instructional activities, evaluation of learning outcomes, and developing students to actualize their potential. In line with this, pedagogical competence can be interpreted into how the teacher understands the students' cognitive and personal in order to make easy in designing the instructional process dealing with determining the instructional strategy based on students' characteristics, the material and the objective of the instructional process and arranging the lesson plan. It is expected that the implementation of instructional process is effective. As an effort to monitor the effectiveness, evaluation is needed so that the result of evaluation process can be used as the reflection to increase the quality of instructional process. It is hoped that students can develop and actualize their potentials academically and non-academically (Suyanto and Jihad, 2013; Hakim, 2015).

As pedagogical competence becomes the ability of teachers to implement instructional activities that directly interacting with students with measurable learning outcomes, the English teachers have the compulsory task to develop themselves in this area. Some previous similar researches have been conducted on the ways of developing pedagogical competence by EFL teachers. First of all, Sumani and Arifin (2017) conducted a study on the ways of improving students as the future candidate of EFL teachers to meet the important role of having pedagogical 
competence. The class of microteaching was employed to train students in recognizing elements of the teachers' pedagogical competencies. By employing this way, the students were trained to do teaching activities, improving their ability to manage the classroom, and doing learning evaluation.

The other study comes from Sulistiyo and Haswindy (2018) where they employed a literature review on a lesson study and teacher professional development programs as some official activities the EFL teachers can do to improve and to maintain their competencies. They emphasize that lesson study is a powerful matter for sustaining EFL teachers' learning to develop their pedagogical competence. Meanwhile, the teacher professional development program also facilitates EFL teachers to master the pedagogical expertise as well as to advance understanding of subject matter knowledge.

The last previous similar research has been conducted by Firman et al., (2019). They conducted a study on the analysis of EFL teachers' pedagogical competence. They mentioned that the teacher tried to do their best in understanding different students' characteristics, identifying the materials as well as testing the students at the beginning of the lesson. Besides that, they also use possible teaching media like laptop, LCD, and use internet connection. The other things they have carried out to develop their pedagogical competency are building communication with students about their scores. Some of them are also conducting action research to know the problem in the classroom.

There is a need of expanding the English teacher pedagogical competency to maximize the pedagogical function to be fulfilled in a modern world using the foreign language in the teaching process as a tool for an entry to new resources and innovative techniques of studying (Panev \& Barakoska, 2015, p. 43). Teaching skill as a part of pedagogical competency required trained teachers as the actor who implement the teaching process that support the success of teaching and learning activities. Based on the result of previous research above, there are various ways the EFL teachers have conducted to develop their pedagogical competencies.

Since it is necessary to always encourage teacher developing their professionalism, this study tried to investigate the ways of secondary EFL teachers employ their pedagogical competences based on the item of pedagogical competence as stated in government regulations Number 19 in the Year of 2005 about the national standard of education mentioned by Suyanto and Jihad (2013, p.41) and Hakim (2015, p. 2) above. Furthermore, it is expected that this research will contribute to the EFL teaching area. Theoretically, this research will describe the specific ways of EFL teachers have been done to improve their pedagogical competences. Meanwhile, practically, this research guides the EFL teachers to implement all pedagogical competences items for their future career of teacher professionalism as stated in official government regulation.

\section{Method}

This research employed a descriptive design with a qualitative approach aimed at describing the ways of EFL teachers developing their pedagogical competencies. There were ten research articles talking about pedagogical studies and those become the source of the study to 
analyze. The reason of ten articles is that those are considered to represent global and universal views of developing pedagogical competence. In spite of more than ten articles, the concept of pedagogical competence is the same. Because of the consideration, the researcher limits 10 articles. The ten research articles would be studied by viewing the perspectives of pedagogical findings to EFL teachers how they build their views in implementing pedagogical competence. Each ten research article describe their theory and practice for implementing pedagogical competence. The way of describing and practicing pedagogical competence illustrates the richness of perspectives of pedagogical competencies that were studied in order to enrich the perspectives of pedagogical competence. Therefore, pedagogical competence in every ten articles determines how EFL teachers in each research article try to give different perspective of teaching to make the teaching interactive and interesting.

The data collection was documentation. In documentation, the researcher used this instrument to get the data dealing with pedagogical competence in order to answer the research problem proposed. Documentation illustrated how the process of pedagogical competence was carried out. Therefore, documentation was the only instrument used in this study. Then, the technique used in collecting the data was searching for research articles dealing with pedagogical competence in the database of articles published online. Searching for them should be in line with the research problem proposed. In searching for them, the researcher not only searched for but also selected the research articles relevant to the research problem proposed. Besides that, getting the main points of the research articles searched for was the next step done by the researcher to make every phase of data collection work systematically. After all main points were collected and displayed based on sorting, the data were considered worthy to analyze.

Conducting data analysis was the last step that was done by the researcher. Content analysis was used to give an analysis toward the data collected (Krippendorf, 2004). In content analysis, every data would be crossed-analyzed to be able to speak for the importance of the research problem proposed. The content analysis aimed to build the multi-perspectives from each ten research articles as the source of data. Content analysis was used to see every finding from the different perspective of pedagogical competence. Because the research articles come from a different level of education, it was intended how deep the analysis of research articles are in giving analysis and explanation dealing with pedagogical competence in theory and practice.

\section{Results and Discussion}

As mentioned above that this study tried to enlarge the perspective on the ways of EFL teachers developing their pedagogical competences. There were ten research articles have been found out in this matter. First of all, Abu and Halim (2017, p. 186) mention in their study that the existence of pedagogical competence the teachers have influenced the way of teaching and students' passion in the classroom. The teachers should be aware of the students' characteristics. Being aware determines the way of teaching and how they respond to the students' needs in learning activities. The students' characteristics that should be understood in strengthening pedagogical competence are dealing with students' potential toward the subject, personality, 
students' ability, learning style, their English skills, students' understanding and their condition during learning in the class, and students' difficulties.

In line with that, Firman et al., (2019, p. 480) state in their research result that the heart of teachers in managing the class relates to their competence in implementing the pedagogical competence. In their lenses, teachers should master the learning theories and the educating principles, develop a curriculum related to the subject of teaching, utilize information and communication technology for learning, facilitate the development of student potentials to actualize their potential, communicate effectively, empathetically, and politely with learners, conduct an assessment and process of evaluation of learning outcomes, utilize the results of assessment and evaluation of learning needs and take the reflective action to increase the quality of learning.

The third article is a study conducted by Suhirman et al., (2016, p. 177) who view the mastery of pedagogical competence when the teachers are contented and satisfied with their work. As a result, they maintain their performance in positive directions. Therefore, if teachers are contented with their job as EFL teachers, they will develop and maintain a high level of performance. To strengthen teachers' pedagogical competence, Irmawati et al., (2017, p. 304) mention three main principles the teachers should have. The first one is individual learning dealing with making use of the internet, reading relevant sources, and doing research. The second one is colleague-related learning discussing the importance of joining teacher association forums, doing team teaching, and having informal discussions. The third one is expert-related learning that covers joining seminars and workshops and joining ELT courses. All those three learning types have positively built upon their pedagogical competence. Furthermore, Siregar et al., (2020, p. 1) view that the teachers' pedagogical competence should be supported with media literacy on how the teachers assimilate technology in the classroom. With the technology they have, it facilitates the learners to get knowledge as open as possible.

Besides that, Abad (2013) adds his view that pedagogical competence also should be enriched with communicative competence, interlanguage, and native language effect. The three elements have contributed to form the English teaching work to achieve the goal. Moreover, Karim et al., (2019, p. 142) in their study state that teachers' knowledge building in order to strengthen their pedagogical competence is the primary focus of the teacher development program. The practice of encouraging students to drag their real-life experiences and expertise into the classroom is the manifestation of classroom management and the class projects make a fine balance between the received and experiential knowledge. Everyone is also required to share their own perceptions and understandings with others.

The other study comes from Sulistiyo (2016, p. 403-404) who states that motivation is an important factor in student engagement. This is the part for them to be able to share. However, teachers must develop abilities and skills to stimulate interest in their students. For example, during lesson preparation, teachers must foster student engagement with carefully designed and clearly stated communicative competence intentions. One way of doing this is by outlining standards that students must meet, and the procedures for assessing performance that will demonstrate these standards. Besides, teachers must be able to create an atmosphere in their 
classroom that is conducive to student learning. To achieve this, competent teachers use a variety of techniques to accommodate and facilitate various learning styles. Therefore, teacher competence is essential to facilitating successful English exposure and learning during classroom activities and teachers' proficiency in spoken language as the model for students in the class has become a critical issue in language learning.

Liu and Kleinsasser (2015, p. 131) as the next researchers who found out in their study that the ability to match students' language levels, evaluating students' project performance, and creating an online cooperative learning environment among students become the part of increasing teachers' pedagogical competence. An interesting finding was proclaimed by Şentürk and Zeybek (2019, p. 77-78) in their study that teachers' teaching-learning conceptions significantly predict their pedagogical competence perceptions. For this reason, there is a need for teachers who have a constructivist teaching-learning conception and who have high pedagogical competence perceptions. By having constructive teaching-learning conceptions, there will be a change and transformation in strengthening pedagogical competence that will be required in the future in the faculties of education.

Pedagogical competence always deals with teachers' competence in the ability to manage the teaching-learning activities, including planning, implementation, and evaluation of learning outcomes of learners. This study has been researched by Abad (2013), Liu and Kleinsasser (2015), Suhirman et al., (2016), Sulistiyo (2016), Abu and Halim (2017), Irmawati et al., (2017), Firman et al., (2019), Karim et al., (2019), Şentürk and Zeybek (2019), and Siregar et al., (2020). They have the unique finding in their study that teachers not only work for delivering and transferring the values and knowledge but also should be able to position themselves as the model in practicing what they teach in the class with the students.

Moore (2000, p. 139) says that teachers should be situational, contextual, practice-based and practitioner-led; problem-centered, interventionist, aimed at improvement; reflexive; collaborative, participatory and collegial; systematic and investigative; emancipatory, empowering, and critical. Because teachers should be all in one to manage their competence in practice, it is very important for them in situating their teaching activities based on the need and the goal of teaching. Students' problem is not only about to receive the knowledge from the teachers but also makes the knowledge easy to understand and to practice. It needs extraordinary energy and effort from the teachers.

Izadinia (2009) states that a teacher should treat learners as autonomous learners, where learner autonomy means not only learning to learn but goes beyond that to include a capacity to learn to liberate. In this context, it is necessary for teachers to raise students' consciousness and prepare them to engage in larger social struggles for liberation. EFL context should be treated as the space for the learners in training their English skills. Teachers' competence in bringing the class interactive and interesting is the way for achieving students' achievement in English skills. What students learn and practice is determined by teachers in designing classroom activities. A teacher in the class is the only facilitator so that this position should be able to liven a positive situation to make the learners active and participative in teaching activities. 
Agnello (2016, p. 30 and 32) gives another illustration dealing with teachers in which they as researchers are inquiry-oriented and as researchers are able to cultivate and respond to situated participation. It means that in teaching English based on ten researchers' study, teachers should define themselves as the people who can make the classroom activities oriented target. In an oriented target, the goals of teaching should be viewed to make the learners learn. By handling the goals of teaching, the teaching activities with the designs made will be applicable. On the other side, teachers' ability in cultivating and responding to situated participation in the classroom is the other one that should be paid attention to. Teachers' pedagogical competence dealing with this content is the reference in driving students to find their mood in learning.

To respond to EFL teaching for the sake of increasing teachers' pedagogical competence, Wong and Waring (2010, p. 276-278) suggest several steps in reconsidering instructional policies in the language classroom. Those are broadening corrective feedback, rethinking task design, and linking practices to participation. In the practice of corrective feedback, once an error or problem surfaces, it is not solely up to the teacher to either identify or fix the problem. The learner can conduct self-initiation, and the peers other-initiation. By the same token, once a problem is identified via repair initiation, the burden of repair does not rest solely upon the teacher. Both self and peer repair are legitimate options.

In rethinking task design, it should relate to what happens in classroom activities. The experiences of classroom activities can be a formulation to create the design of teaching that is more interesting and interactive, responsive to students' needs based on the goal of teaching. It is expected to promote learner contributions to the direction and outcome of their learning activity. In linking practices to participation, it deals with creating a productive learning environment. Refraining from turning every opportunity into a testing activity as well as taking risks in making relevant the various identities of both the teacher and the learners is the way to invite students to participate in the class. In teaching, it is important for EFL teachers to attend to reduce or negate learners' psychological pressures, such as anxiety and fear so that they feel happy about learning (Wilson \& Lewandowska-Tomaszczyk, 2020).

González and Cramer (2018) say that to be good and interactive teachers in the classroom, they should be able to use dialogue and intercultural communication pedagogy. Through dialogue, The EFL teacher and students are in the same field to share, especially students' feelings and mind what to say. The students feel at home and relaxed with their teacher. Through intercultural communication pedagogy, the teacher uses an approach that makes the learners safe and treated with their different backgrounds of culture. Although they have any problems with communication in uttering their expressions, the teacher let them speak and learn EFL as the language learned. With the teacher's existence that treat all students with comfort, the teachinglearning activity becomes useful and is interesting. Learning English for the learners is charming because the teacher implements the teaching way that is interactive and respects the difference in students' way of English expressions. 


\section{Conclusion}

The fact that pedagogical competence is needed by ELF teachers to assist and drive them in managing the class is a must. The EFL teachers' competence in pedagogy should be enriched and strengthen so that they can develop their potentials as interactive teachers in the classroom. Teachers' pedagogical competence, such as designing material, teaching-learning process, evaluation, and reflecting to get better feedback in the next teaching-learning activities should be trained continuously to make them habituated in the teaching process. What has been studied in this study by discussing ten research articles dealing with pedagogy in TEFL highlight the importance of flexibility and contextuality in managing pedagogy to manage the classroom and finally to reach the goal of teaching.

\section{References}

Abad, J. V. (2013). Pedagogical factors that influence EFL teaching: Some considerations for teachers' professional development. PROFILE, 15(1), 97-108.

Abu, U. A., \& Halim, A. (2017). Effective EFL teachers as viewed by senior high school students. ELT Worldwide, 4(2), 180-194.

Agnello, M. F. (2016). The dispositions of teachers as researchers: A call to action. In M. F. Agnello \& W. M. R. Editors (Eds.), Practicing critical pedagogy: The influences of Joe L. Kincheloe (pp. 29-36). New York: Springer International Publishing AG.

Firman, F., Tersta, F. W., Riantoni, C., \& Sekonda, F. A. (2019). An analysis of English as a foreign language (EFL) teacher' pedagogical competence and readiness in maintaining the implementation of the 2013 curriculum. Educational Research and Reviews, 14(13), 474483. https://doi.org/10.5897/ERR2019.3705

González, A., \& Cramer, L. (2018). Dialogue and intercultural communication pedagogy. In A. Atay \& S. Toyosaki (Eds.), Critical intercultural communication pedagogy. Maryland: Lexington Books.

Hakim, A. (2015). Contribution of competence teacher (pedagogical, personality, professional competence, and social) on the performance of learning. The International Journal of Engineering and Science, 4(2), 1-12.

Irmawati, D. K., Widiati, U., \& Cahyono, B. Y. (2017). How do Indonesian professional English teachers develop their pedagogical competence in teaching implementation? Arab World English Journal (AWEJ), 8(2), 293-307.

Izadinia, M. (2009). Critical pedagogy: An introduction. In P. Wachob (Ed.), Power in the EFL classroom: Critical pedagogy in the Middle East (pp. 7-16). Newcastle: Cambridge Scholars Publishing.

Karim, A., Shahed, F. H., Mohamed, A. R., Rahman, M. M., \& Ismail, S. A. M. M. (2019). Evaluation of the teacher education programs in EFL context: A testimony of student teachers' perspective. International Journal of Instruction, 12(1), 127-146. https://doi.org/10.29333/iji.2019.1219a

Krippendorff, K. (2004). Content analysis: An introduction to its methodology (2nd ed.). 
Thousand Oaks, California: Sage Inc. https://doi.org/10.1103/PhysRevB.31.3460

Liu, M., \& Kleinsasser, R. C. (2015). Exploring EFL teachers' call knowledge and competencies: In-service program perspectives. Language Learning \& Technology, 19(1), $119-138$.

Moore, A. (2000). Teaching and learning: Pedagogy, curriculum, and culture. In A. Moore (Ed.). London: RoutledgeFalmer.

Panev, V., \& Barakoska, A. (2015). The need of strengthening the pedagogical competencies in teaching from the English teachers' perspective. International Journal of Cognitive Research in Science, Engineering and Education, 3(1), 43-50.

Pemerintah Republik Indonesia. (2005). Act about teachers and lecturers No. /2005. Statute book. Jakarta: Pemerintah Republik Indonesia.

Şentürk, C., \& Zeybek, G. (2019). Teaching-learning conceptions and pedagogical competence perceptions of teachers: A correlational research. Research in Pedagogy, 9(1), 65-80. https://doi.org/10.17810/2015.92

Siregar, R. A., Fauziat, E., \& Marmanto, S. (2020). An exploration on EFL teachers' perceptions of effective 21st century pedagogical competences. JEELS (Journal of English Education and Linguistics Studies), 7(1), 1-24.

Suhirman, L., Atmowardoyo, H., \& Husain, D. (2016). Perception of EFL teachers' satisfaction on pedagogical process. International Journal of English Linguistics, 6(5), 170-179. https://doi.org/10.5539/ijel.v6n5p170

Sulistiyo, U. (2016). English language teaching and EFL teacher. In Proceedings of the Fourth International Seminar on English Language and Teaching (ISELT) (pp. 396-406).

Sulistiyo, U., \& Haswindy, S. (2018). Organizing professional and pedagogical training to improve English teachers' skills: A literature review. Jurnal Pendidikan dan Pengajaran, 5(2), 167-174.

Sumani, \& Arifin, S. (2017). The EFL pre-services teachers' pedagogical competence based on the instructional approach. In international conference on English language teaching (ICONELT) (Vol. 145, pp. 204-207).

Suyanto, \& Jihad, A. (2013). Menjadi guru profesional: Strategi meningkatkan kualifikasi dan kualitas guru di era global. Jakarta: Esensi.

Tanang, H., \& Abu, B. (2014). Teacher professionalism and professional development practices in South Sulawesi, Indonesia. Journal of Curriculum and Teaching, 3(2), 25-42. https://doi.org/10.5430/jct.v3n2p25

Wardoyo, C. (2015). The measurement of teacher's personality competence and performance using embedded model. Journal of Education and Practice, 6(26), 18-24.

Wilson, P. A., \& Lewandowska-Tomaszczyk, B. (2020). Effects of non-native versus native teaching scenarios on L2 student emotions. In G. Drożdż \& B. Taraszka-Drożdż (Eds.), Foreign language pedagogy in the light of cognitive linguistics research. Cham.

Wong, J., \& Waring, H. Z. (2010). Conversation analysis and second language pedagogy. New York and London: Routledge. 